\title{
The Mexican Environmental Flow Standard: Scope, Application and Implementation
}

\author{
María Antonieta Gómez-Balandra, María del Pilar Saldaña-Fabela, Maricela Martínez-Jiménez
}

Hydrobiology and Environmental Assessment Department, Mexican Institute of Water Technology, Jiutepec, México. Email: magomez@tlaloc.imta.mx

Received November $8^{\text {th }}, 2013$; revised December $11^{\text {th }}, 2013$; accepted January $5^{\text {th }}, 2014$

Copyright (c 2014 María Antonieta Gómez-Balandra et al. This is an open access article distributed under the Creative Commons Attribution License, which permits unrestricted use, distribution, and reproduction in any medium, provided the original work is properly cited. In accordance of the Creative Commons Attribution License all Copyrights (C) 2014 are reserved for SCIRP and the owner of the intellectual property María Antonieta Gómez-Balandra et al. All Copyright (C) 2014 are guarded by law and by SCIRP as a guardian.

\section{ABSTRACT}

With the implementation of the Official Mexican Standard NOM-011-CONAGUA-2000 [1], the water balance of 730 basins has been calculated and its water availability agreement is published. This rule points out to allocate water for the environment only as an annual volume since methods for estimating environmental flows were not standardized in the country. For this reason, The Water Agency (CONAGUA) issued the standard NMX-AA159-SCFI-2012 [2], to assess environmental flows needed both, at the strategic level in Integrated Water Resources Management (IWRM), or as part of the Environmental Impact Assessment (EIA) of large hydraulic projects. For over ten years, this standard was developed and finally published in September 2012 [3]. It explains different methods from hydrological to holistic approaches, with examples for the country. Its application will cover the urgent need to preserve water for ecosystems in watersheds with high ecological importance and low stress for water use. In this paper, an analysis of the environmental flow standard and examples of the suggested hydrological methods are presented. For its implementation, some steps are taking place, mainly establishing environmental water reserves and building capacities. In addition, environmental allocations are becoming a common practice for all water projects, as well as setting limits to hydrological alterations by hydroelectric dams. The standard promotes the use of technical integration tools to analyze the responses of ecosystems to changes in the flow regime and adaptive management under different scenarios of water use. Although the main steps have been taken, its implementation as mandatory rule will take time.

\section{KEYWORDS}

Environmental Flows; Hydrological Methods; Mexican Standard

\section{Introduction}

Environmental, ecological or in stream flow (EF) is the amount of water that is kept flowing down in order to maintain the river in a desired environmental condition in terms of its spatial and timing distribution required to maintain the components, functions and aquatic ecosystems processes from which people obtain benefits ([4-10]. The concept has evolved to recognize the natural variability of flow regimes which consider: magnitude, duration, timing, frequency and rate of change associated to environmental services and ecosystems resilience [11].

Environmental flow assessment (EFA) is based on a scientific process to deal with basin features, probabilis- tic variability of natural flows and cross section hydromorphology models. These issues determine habitat connectivity and availability to be used by species at several stages of their life cycle. EFA is also a social process since water regulators and users define the level of stress that can be supported by a river in terms of their quantity, quality and ecosystem services, although not many of these decisions have been properly taken. Then, generalized flow standards can be used to allocate water for the environment [12] but, every river can have an environmental flow regime according to what people want from a river in terms of conservation and use [13].

EFA as an escalated set of methodologies is becoming 
an important toolbox to assess sequentially from rivers' natural flow regime to its ecological integrity (structure, function, processes and alterations). Methods have been classified as: hydrological, hydraulics, for habitat simulation and holistic [9,14-17]). Hydrological approaches are the basis to identify the natural flow regime and its alterations caused by water subtractions or hydraulic infrastructure $[11,18]$. Results are complemented with hydraulic measurements and associated to habitat availability and connectivity among aquatic, riparian and coastal communities. In addition, holistic approaches consider environmental services for people and comparison of water allocation strategies or altered scenarios by infrastructure [19]. Due to the condition of many rivers which are over-allocated, fragmented, polluted and losing biodiversity, it is recognized that EFA is needed as a part of approaches both at strategic level in the integrated water resource management IWRM and as a part of EIA for large hydraulic projects [20-22]

The EF implementation is on progress and overcoming several drags, since hydrological records are sometimes the only available data for many regions, whereas hydraulic studies are really scarce and its development is time and cost consuming [9]. Besides, these methods need to broaden their scope towards habitat availability for species, not only as hydraulics research. This approach is under development since several disciplines are involved and need to formulate flow alteration-habitat availability—ecological responses hypothesis to be tested through different indicators. The final goal is to deal with an adaptive approach both to operate hydraulic infrastructure and produce conditions for preserving species, maybe in the year by year basis. Thus the final output is to reduce the effects of anthropogenic activities on aquatic ecosystems. Changes can be followed by hydrological parameters, habitat availability, species presence-absence, condition factor, weight-length relationship and food webs, among others [23]

\section{EFA Mexican Approach}

The "environmental water use or use for ecological conservation" is defined by the National Water Law as "the minimum flow or volume required in receiving water bodies, including streams or reservoirs, or the minimum flow of natural discharge from one aquifer that must be maintained to protect environmental conditions and the ecological balance.

The specific definition of Ecological Flow in the Mexican Standard [2], which establishes the procedure to determine the environmental flow is: the quantity, quality, and flow variations or water levels required to preserve environmental services, components, functions, processes and the resilience of aquatic and terrestrial ecosystems. They depend on the hydrological, geomorphological, ecological and social processes. This implies that in addition to provide water for domestic, urban public, livestock and agriculture uses, it is possible to maintain flows from both runoff and aquifer outcropto preserverivers (perennial, intermittent and ephemeral), lenticwater bodies (lakes, ponds, and wetlands), and riparian ecosystems.

The need for ecological flows was a pendant issue since the Water Act publication in 1992 and re -emerged with the application of an Official National Standard [1], to set basins' water availability. This availability comprises a committed natural discharge as a fraction of the hydrogeological unit of natural discharge, committed as superficial water to diverse uses or to be preserved to prevent negative impacts on ecosystems or the migration of bad quality water into the aquifer. The estimated water availability is then published in each hydrometric gauge of the basin and as a total volume.

The Mexican Standard to estimate the EF is a technical guideline rather than a compulsory limit [2]. Its main scientific principles are: the recognition of natural hydrological regime and the gradient of the biological condition. Therefore, any methodology is valid for the standard as long as it focuses on understanding the ecological significance of each component of the natural flow regime, and it generates proposals for its conservation or restoration in whole or partially, from the functional point of view.

Following a top-down initiative and based on the gradients of ecological importance and water scarcity, an environmental objective (EO) was assigned such as water availability is issued for each basin or sub-basin in the country (Figure 1). The Rio Verde sub-basins were numbered for further analysis.

The EF Mexican standard calls for the application of hydrological methods as the basis to reserve or allocate water for the environment. Therefore, according to the EO's, reference values (\% of medium annual volume or flow) as well as the components of a seasonal flow regime are stated as follows:

1) Under a modified Tennant approach (García et al. [5]).

a) Percentage of mean annual flow (MAF) with different seasonal percentages (Reference values).

b) Percentage of monthly mean flows MMF.

c) A base flow during dry season not less than the historical minimum monthly flow (MinF).

2) Under WWF Mexico approach.

a) A total volume associated to an ordinary regime (TVOR), considering wet, medium and dry years.

b) A total volume related to the frequency of floods' regime (TVFR) with a return period of $1,1.5$ and 5 years to be reproduced within 10 years return period according to EO's.

3) Under TNC approach [14].

a) Intra and inter-annual natural variability. 


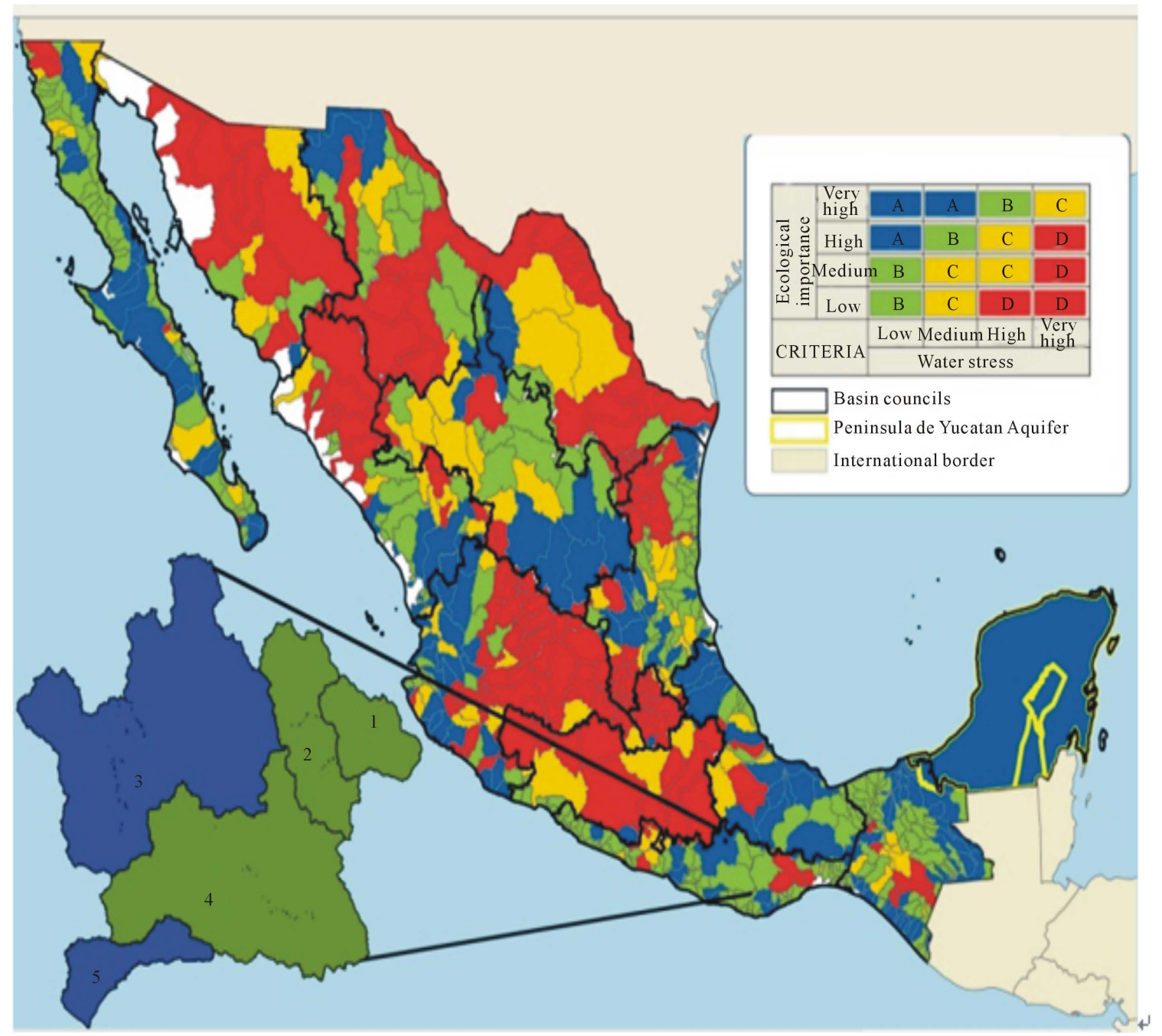

Figure 1. Environmental objectives for the Mexican basins and the Rio Verde Basin (Modified from WWF, [24]).

b) Thresholds for hydrological alterations on hydrological parameters with ecological importance (monthly flows, $1,7,30$ and 90 days minimum and maximum flows).

These approaches can be applied at basins, sub-basins or river reaches as it is pointed out in Figure 2. At least 20 years of hydrological data are recommended for all these analysis.

The Mexican flow standard also describes some initial experiences in using habitat simulation with BBM building blocks methodology [24] as holistic approach and recommends the use of habitat simulation methods like PHabSim or others.

\subsection{EFA Hydrological Methods Application}

The Environmental objectives for the Rio Verde Basin and sub-basins located in the hydrological region 20 named Costa Chica de Guerrero were stated as is pointed out in Table 1.
The hydrological gauge Paso de la Reina was chosen to show result from the standard application (Figure 3) in this site a proposed hydro project is under planning studies.

\subsection{Modified Tennant Approach ([5])}

\section{General steps:}

1) Selection of the site of study.

2) Analysis of the monthly dataset.

3) Determination of monthly and annual flow regime.

4) Formulation of proposals for monthly and annual environmental flow regime.

As mentioned above, the selected site was the Paso de la Reina hydrometric gauge, this gauge has 45 years of records. For this approach, the start of the monthly series begins in May because is the month when the rain season begins. The monthly flow regime (MMF) was stated as well as the mean annual flow (MAF) as the reference started points (Figure 4). 
According to environmental objectives (EO), Table 2 shows recommended seasonal flow percentages. Tennant modified by García et al. [5,26], and proposed by [25].

As Paso de la Reina site was classified as Environmental Objective "A" [2], then annual and monthly allocated percentages are shown in Figure 5.

After setting percentages it must be reviewed that environmental flow in dry season should never be greater than the monthly average flow (MMF) nor lesser than the base flow.

The environmental flow proposal is based on monthly percentages (light green area in Figure 6 and values of Table 3). For dry years the proposal can be adjusted up to seasonal thresholds (30\% and $60 \%$ of MAF blueline). For rain season these limits can be set between percentages of mean annual flow MAF (blue line) and monthly mean flow (dark green area). For each stream, a base flow must be estimated (blackline).

\subsection{WWF Approach}

According to the World Wildlife Fund Mexico approach a reference volume as percentage of the medium annual flow should be equal or greater than $40 \%$ (Table 4).

The next step is to identify alterations in the hydrological regime trough dividing time series data in two periods. For the first set of 20 years (natural hydrological regimen RHN) obtain percentiles 10 and 90 and check if the number of the monthly means of the second period (present hydrological regime RHA) that are within these limits. If the fulfillment of the actual regime (RHA) is $<50 \%$ in relation to percentiles (RHN) the river is considered altered. The Figures 7 and 8 pointed out that the Rio Verde at Paso de la Reina hydrometric gauge is not altered.

For seasonal environmental flow estimation, the Total Ordinary Volume Regime (TOVR) and the Total Volume for Flood Regime (TVFR) were obtained using the procedure proposed by World Wildlife Fund Mexico at the study basin level. TOVR was obtained multiplying the frequency by volume for each year condition to be reproduced with regards to the environmental objective (Table 5).

The two steps to calculate TVFR that try to resemble natural pattern, according to the conservation objectives, were:

1) Classification and characterization of peaks: To separate flood types initially used the criterion of magnitude, maximum flow and probability of occurrence over time (frequency). Analysis of statistical distributions are needed to determine magnitude of floods associated re-

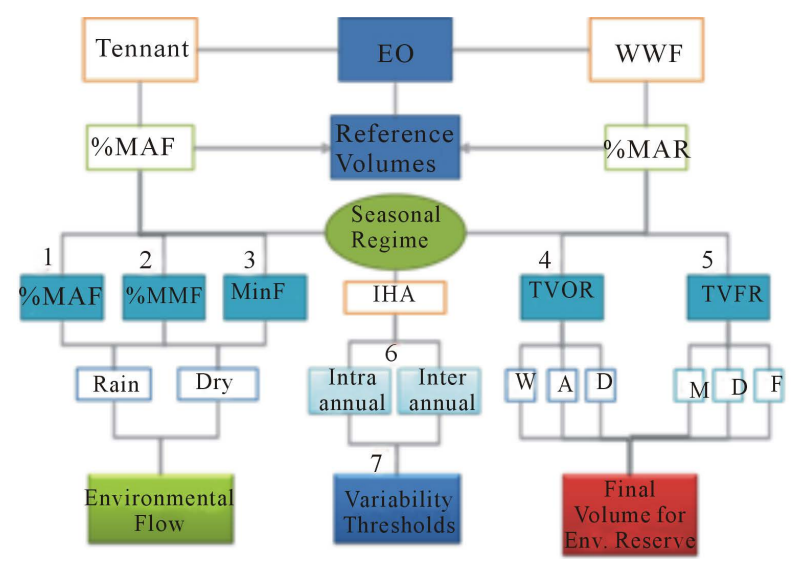

Figure 2. EFA hydrological approaches in the Mexican standard.

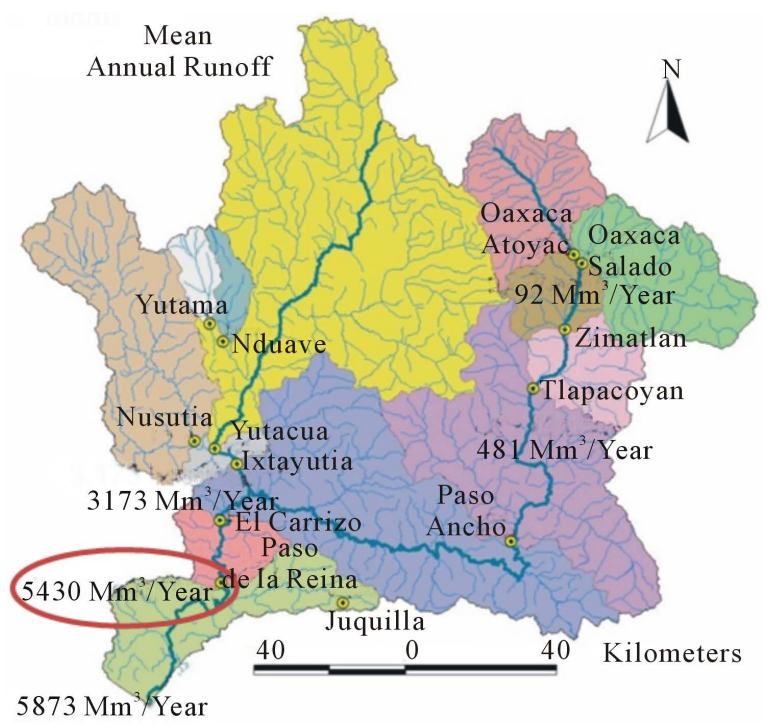

Figure 3. Water availability issued for the basin. CFR: 05/ 07/2013 [25].

Table 1. Environmental objectives by sub-basin.

\begin{tabular}{cccccc}
\hline Rio Verde Sub-basins & 1 & 2 & 3 & 4 & 5 \\
\hline Annual Availability (Mm³/year) & 92.4 & 481.1 & 3173.8 & 5430.3 & 5873.3 \\
Ecological Importance & High & High & High & Medium & High \\
Water use stress & Medium & Medium & Low & Low & Low \\
Present/Desired Condition & Good & Good & Very Good & Good & Very Good \\
Environmental Objective & B & B & A & B \\
\hline
\end{tabular}




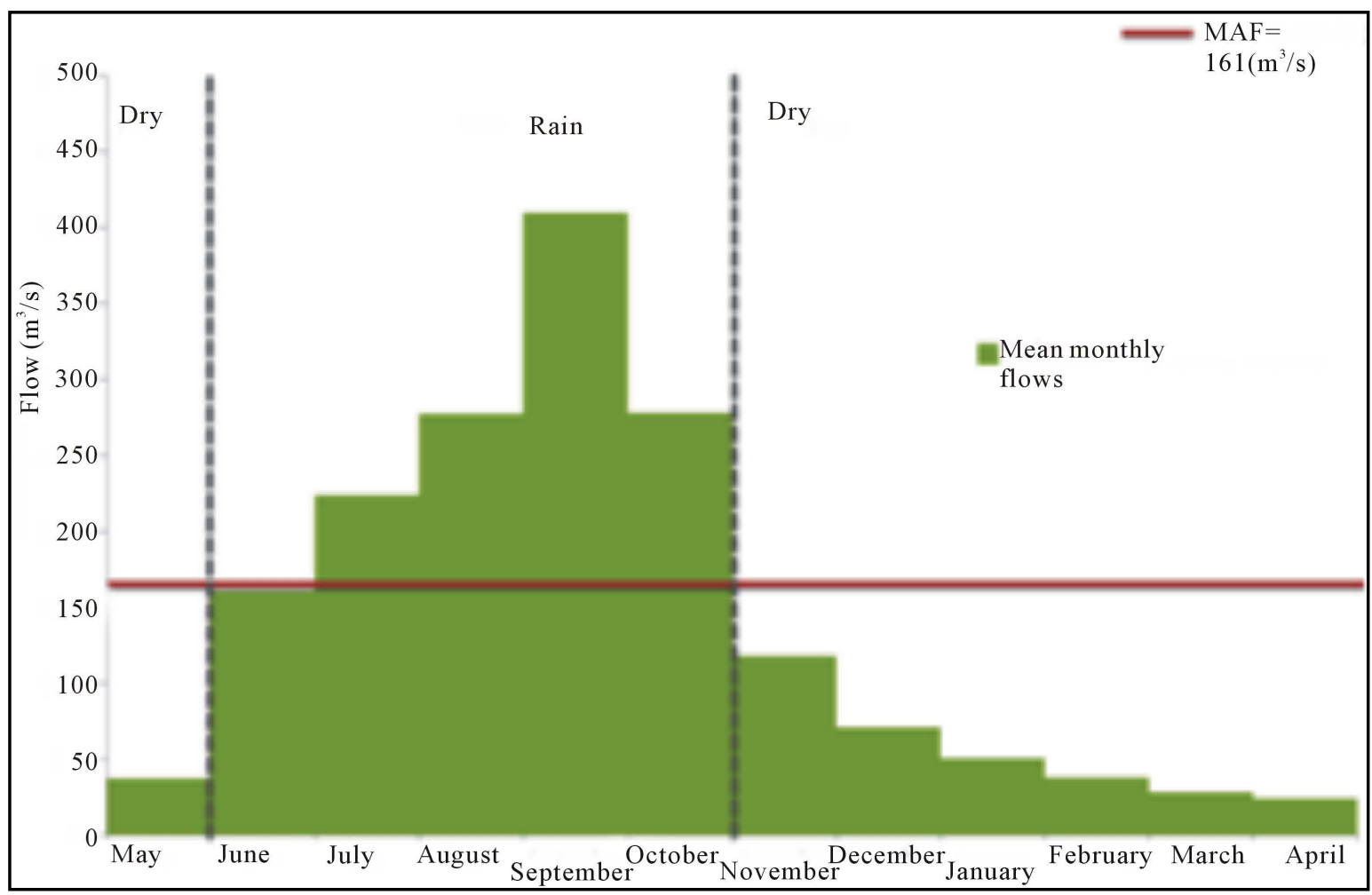

Figure 4. Monthly flow regime and mean annual flow that determines the dry and rainy seasons.

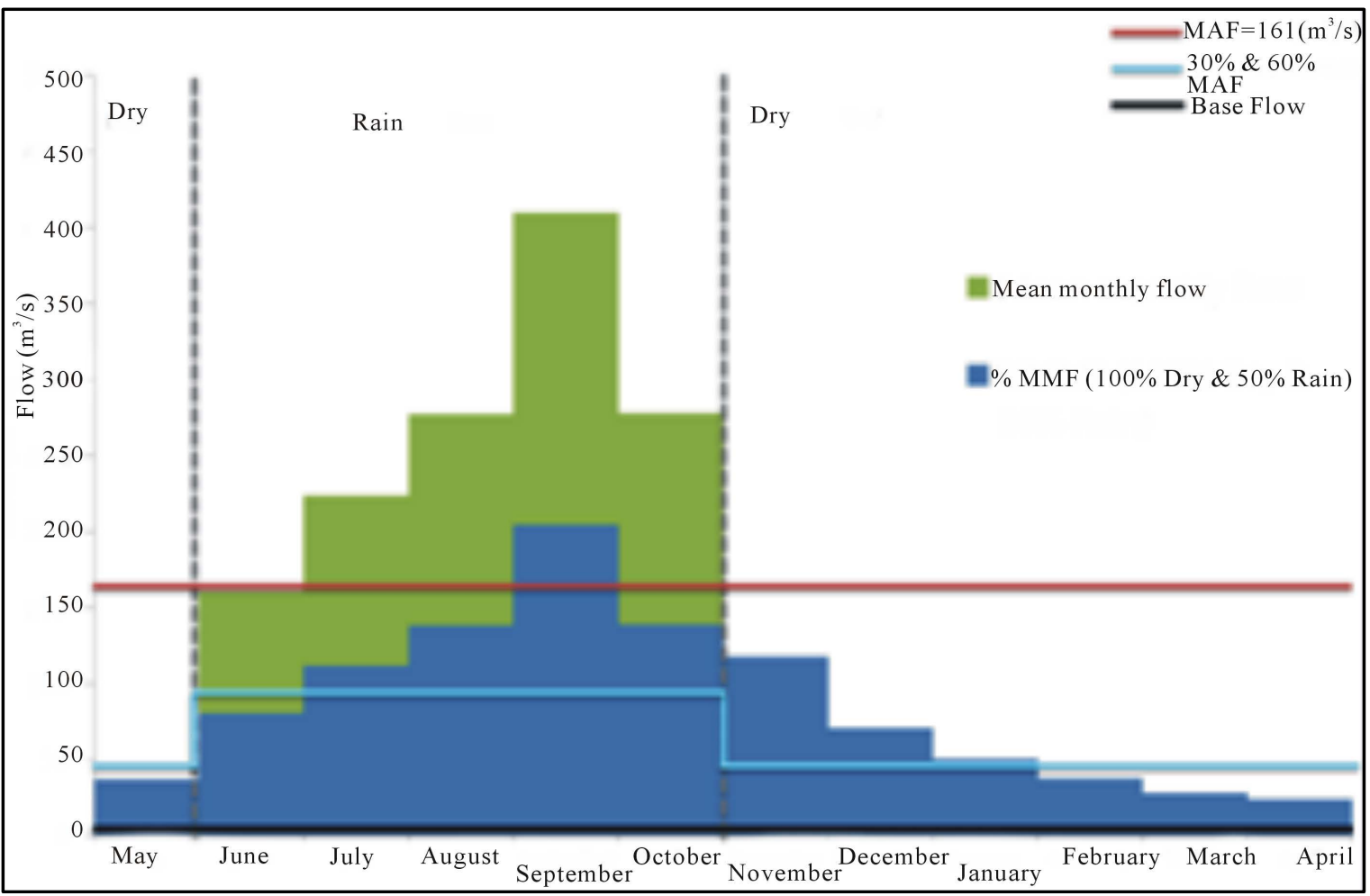

Figure 5. Annual and monthly allocated percentages.

turn periods as follows:

a) Runoff with return period of 1 year (Category I). b) Runoff with return period of 1.5 years (Category II).

c) Runoff with return period of 5 years (Category III). 


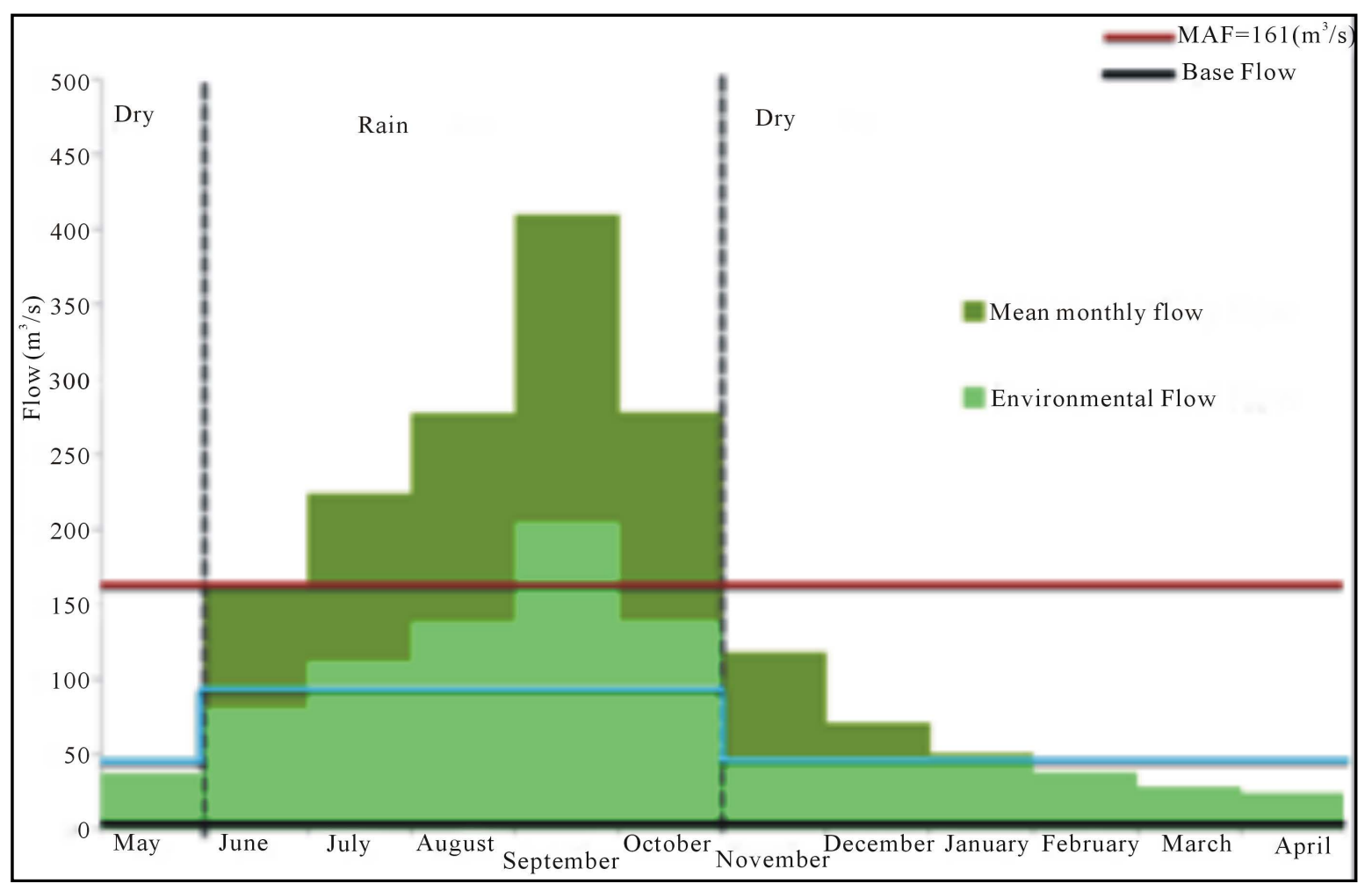

Figure 6. Environmental flow proposal.

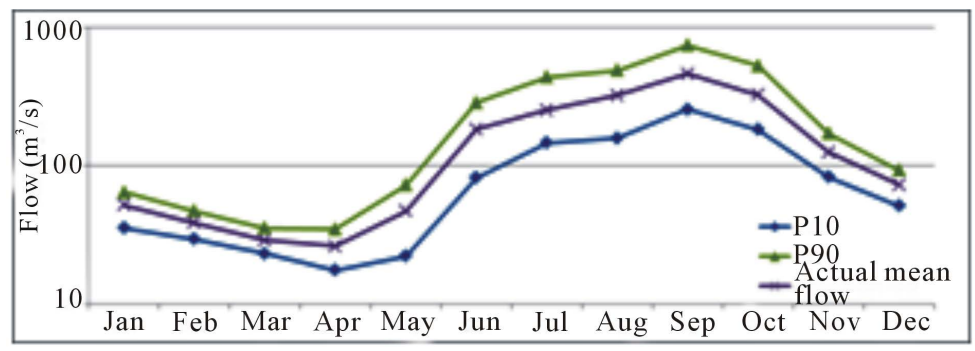

Figure 7. Monthly present mean and RHN limits.

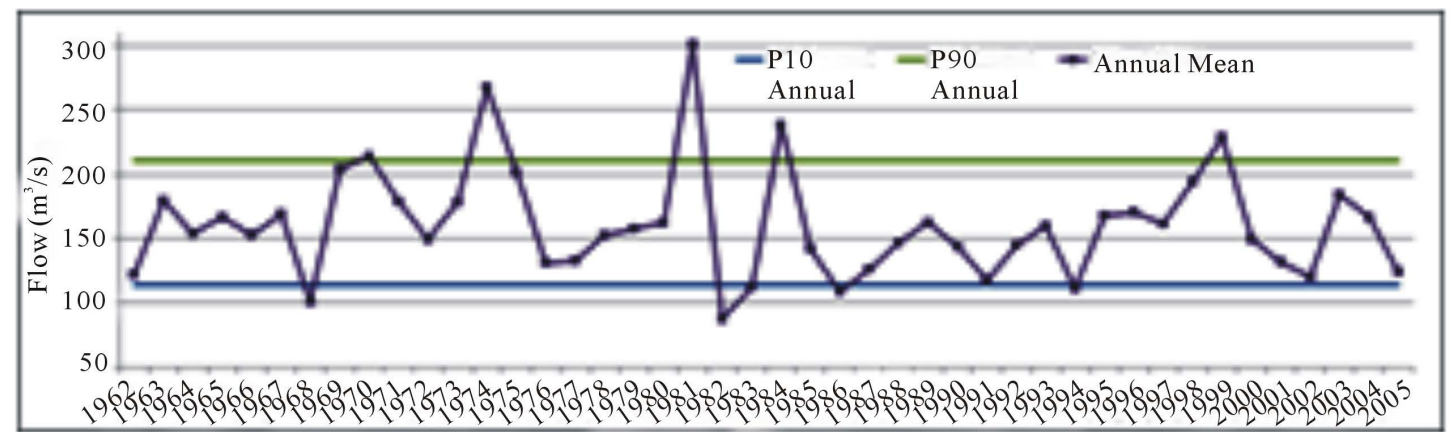

Figure 8. Annual present mean and RHN limits.

2) Duration in days of each runoff period is then obtained and the product of this duration, frequency and volume resulted in the Total Volume for Flood Regime for three different runoffs within 10 years. Table 6 shows the results for these calculations.
The integration of the final reserved volume (FRV) or environmental flow to be considered in the annual water balance of the basin and its water availability is the sum of total ordinary volume regime (TOVR) with the total volume of flood regime (TVFR), as follows: 
Table 2. Reference values for each EO.

\begin{tabular}{ccccc}
\hline \multirow{2}{*}{$\begin{array}{c}\text { Environmental } \\
\text { Objective }\end{array}$} & \multicolumn{3}{c}{ Dry } & \multicolumn{3}{c}{ Rain } \\
\cline { 2 - 5 } & $\% M A F$ & $\% M M F$ & $\% M A F$ & $\% M M F$ \\
\hline A & 30 & 100 & 60 & 50 \\
B & 20 & 80 & 40 & 40 \\
C & 15 & 60 & 30 & 30 \\
D & 5 & 40 & 10 & 20 \\
\hline
\end{tabular}

Table 3. Monthly environmental flow regime in cubic meters per second $\left(\mathrm{m}^{3} / \mathrm{s}\right)$.

\begin{tabular}{cc}
\hline Month & Environmental Flow \\
\hline January & 48.3 \\
February & 37.8 \\
March & 28.3 \\
April & 24.2 \\
May & 37 \\
June & 80.4 \\
July & 111.9 \\
August & 138.7 \\
September & 204.8 \\
October & 139.2 \\
November & 48.3 \\
December & 48.3 \\
\hline
\end{tabular}

Table 4. Reference values for specific environmental objectives.

\begin{tabular}{ccc}
\hline $\begin{array}{c}\text { Environmental } \\
\text { Objective }\end{array}$ & $\begin{array}{c}\text { Conservation } \\
\text { Gradient }\end{array}$ & $\begin{array}{c}\text { Environmental Flow }(\% \mathrm{MAF}) \\
\text { Perennial streams }\end{array}$ \\
\hline \multirow{2}{*}{ A } & Very good & $>40$ \\
& & $>64.6 \mathrm{~m}^{3} / \mathrm{s}$ or $>2172 \mathrm{Mm}^{3} /$ year \\
\hline
\end{tabular}

Table 5. Total Ordinary Volume Regime.

\begin{tabular}{ccccc}
\hline Type of Year & Very dry & Dry & Average & Wet \\
\hline Percentile & $P 0$ & $P 10$ & $P 25$ & $P 75$ \\
$\begin{array}{c}\text { Ordinary volume regime } \\
\text { (OVR Mm } \text { Mear) }^{3}\end{array}$ & 2052 & 2862 & 3611 & 6066 \\
\% Mean Annual Runoff & 40 & 56 & 71 & 119 \\
$\begin{array}{c}\text { Frequency } \\
\text { Total Ordinary }\end{array}$ & 0.2 & 0.3 & 0.4 & 0.1 \\
Volume Regime & & $3319 \mathrm{Mm}^{3} /$ year & \\
\hline
\end{tabular}

$$
\begin{gathered}
\text { FRV }=\text { TOVR }+ \text { TVFR } \\
\text { FRV }=\mathbf{3 3 1 9}+\mathbf{1 9 8}=\mathbf{3 5 1 7} \mathrm{Mm}^{3} / \text { year }
\end{gathered}
$$

Table 6. Total Volume of Flood Regime.

\begin{tabular}{cccc}
\hline $\begin{array}{c}\text { Attribute of } \\
\text { hydrological regime }\end{array}$ & Category I & Category II & Category III \\
\hline Magnitude & $\begin{array}{c}1 \text { year } \\
\text { return }\end{array}$ & $\begin{array}{c}1.5 \text { years } \\
\text { return }\end{array}$ & $\begin{array}{c}5 \text { years } \\
\text { return }\end{array}$ \\
Mm $\mathrm{mm}^{3} / \mathrm{s}$ day & 303 & 843 & 1874 \\
Frequency & 26 & 73 & 162 \\
Duration & 10 & 6 & 2 \\
Timing & 3 & 2 & 1 \\
Rate of Rise \\
change Fall
\end{tabular}

$$
\begin{gathered}
\text { MAR }=5430 \mathrm{Mm}^{3} / \text { year } \\
\text { FRV }=3517 \mathrm{Mm}^{3} / \text { Year }=64 \% \text { of MAR }
\end{gathered}
$$

\section{Conclusions}

Although the Mexican Water Act states the environmental use and the Availability Standard points out an annual volume to the environment in each basin, for more than fifteen years, the minimum flow as much as $10 \%$ of monthly flows have prevailed to deal with environmental allocation of water for projects with consumptive uses (water supply and irrigation). Availability agreements have been issued and are going to be reviewed every two years. Therefore, implementing EFA is the next challenge to be included in these agreements and then gives some priority of reserving water for the environment [27].

The Mexican environmental flow standard as a technical procedure gives the support to move ahead from this $10 \%$ minimum approach and consider the natural flow variability. Through the recognition of this natural variability and applying at least hydrological methods, twofold protection goals can be achieved to: 1) Reproduce seasonal and even monthly variability and 2) Consider thresholds for alteration either seasonal, monthly or inter-annually when ecological process can be vulnerable.

The hydrological methods are also the basis for the regional water resources management under frameworks like the integrated watershed resource management IWRM and the ecological limits of hydrological alteration (ELOHA) [28]

The application of habitat simulation and holistic methods is under development in Mexico. Therefore, experiences at regional and basin level as well as for large infrastructure projects are an urgent need to protect the 
ecological integrity of ecosystems. These approaches should be integrative and under an interdisciplinary approach.

As a result of the application of habitat simulation or holistic methods, a set of ecological and social indicators can be obtained to follow during the EF implementation. For Mexico, the regional ecosystem changes and social responses will be valuable when the adaptive approach has to consider tradeoffs between ecological conservation and water use tightening further hydraulic development.

\section{REFERENCES}

[1] NOM-011-CNA-2000, “Norma Oficial Mexicana, Conservación del Recurso Agua. Que Establece las Especificaciones y el Método para Disponibilidad Media Anual de las Aguas Nacionales,” DOF 17-Abril-2002, México, p. 20.

[2] NMX-AA-159-SCFI-2012, “Norma Mexicana. Que Establece el Procedimiento para la Determinación del Caudal Ecológico en Cuencas Hidrológicas,” DOF 20 de Septiembre de 2012, México, p. 123.

[3] P. A. E. Lis, M. A. G. Balandra and P. S. Fabela, "Requerimientos para Implementar el Caudal Ambiental en México,” Instituto Mexicano de Tecnología del Agua, Alianza World Wildlife Fund/Fundación Gonzalo Río Arronte. Programa Hidrológico Internacional UNESCO, SEMARNAT, 2007, p. 176.

[4] T. Annear, I. Chisholm, H. Beecher and A. Locke, "Instream flows for Riverine Resource Steweardship,” Revised Edition, Instream Flow Council, Cheyenne, 2004, p. 268.

[5] E. García, R. González, P. Martínez, J. Athala and G. Paz-Soldán, "Guía de Aplicación de los Métodos de cálculo de Caudales de Reserva Ecológicos en México, Colección,” CNA-IMTA-SEMARNAP, México D.F., 1999, p. 190.

[6] S. Postel and B. Richter, "Rivers for Life: Managing Water for People and Nature,” Island Press, Washington DC, 2003.

[7] N. L. Poff, "Managing for Variability to Sustain Freshwater Ecosystems," Journal of Water Resources Planning and Management, Vol. 135, No. 1, 2009, pp. 1-4.

[8] A. H. Arthington, S. E. Bunn, N. L. Poff and R. J. Naiman, "The Challenge of Providing Environmental Flow Rules to Sustain River Ecosystems,” Ecological Applications: A Publication of the Ecological Society of America, Vol. 16, No. 4, 2006, pp. 1311-1138.

[9] R. E. Tharme, “A Global Perspective on Environmental Flow Assessment: Emerging Trends in the Development and Application of Environmental Flow Methodologies for Rivers,” River Research and Applications, Vol. 19, No. 5-6, 2003, pp. 397-441. http://dx.doi.org/10.1002/rra.736

[10] M. Acreman and M. J. Dunbar, "Defining Environmental River Flow Requirements a Review,” Hydrology and
Earth System Sciences, Vol. 8, No. 5, 2004, pp. 861-876. http://dx.doi.org/10.5194/hess-8-861-2004

[11] B. D. Richter, J. V. Baumgartner, R. Wigington and D. P. Braun, “How Much Water Does A River Need?” Freshwater Biology, Vol. 37, No. 1, 1997, pp. 231-249. http://dx.doi.org/10.1046/j.1365-2427.1997.00153.x

[12] B. D. Richter, "Short Communication Re-Thinking Environmental Flows: From Allocations and Reserves to Sustainability Boundaries," River Research and Applications, Vol. 26, No. 8, 2010, pp. 1052-1063.

[13] J. O’Keeffe and T. Le Quesne, "Keeping Rivers AliveA Primer on Environmental Flows and Their Assessment," World Wildlife Found-Water Security Series 2, Surrey, 2009.

[14] TNC (The Nature Conservancy), "Indicators of Hydrologic Alteration,” Version 7.1 User’s Manual, 2009, p. 81.

[15] WWF and Fundación Gonzalo Río Arronte, “Guía Para la Determinación de Caudal Ecológico en México Sistematización de Experiencias de la Alianza WWF,” Fundación Gonzalo Río Arronte I.A.P., Mexico D.F., 2011.

[16] M. J. DUNBAR and M. C. Acreman, "Applied Hydro-Ecological Science for the Twenty-First Century,” In: M. C. Acreman, Ed., Hydro-Ecology: Linking Hydrology and Aquatic Ecology (Proceedings of an International Workshop (HW2). Centre for Ecology and Hydrology (Formerly Institute of Hydrology), Wallingford, Oxfordshire, 2001, pp. 1-18.

[17] R. Hirji and R. Davis, "Environmental Flows in Water Resources Policies, Plans and Projects. Case Studies,” Water Resources, No. 117. Washington DC, 2009, p. 181.

[18] N. L. Poff, J. D. Allan, M. A. Palmer, D. D. Hart, B. D. Richter, A. H. Arthington, K. H. Rogers, J. L. Meyer and J. A. Stanford, "River Flows and Water Wars: Emerging Science for Environmental Decision Making,” Frontiers in Ecology and the Environment, Vol. 1, No. 6, 2003, pp. 298-306.

http://dx.doi.org/10.1890/1540-9295(2003)001[0298:RF AWWE]2.0.CO;2

[19] A. H. Arthington, R. J. Naiman, M. E. McClain and C. Nilsson, "Preserving the Biodiversity and Ecological Services of Rivers: New Challenges and Research Opportunities,” Freshwater Biology, Vol. 55, No. 1, 2009, pp. 1-16. http://dx.doi.org/10.1111/j.1365-2427.2009.02340.x

[20] C. Nilsson and B. M. Renöfält, "Linking Flow Regime and Water Quality in Rivers: A Challenge to Adaptive Catchment Management," Ecology and Society, Vol. 13, No. 2, 2008, 20 p.

[21] C. J. Vörösmarty, P. B. McIntyre, M. O. Gessner, D. Dudgeon, A. Prusevich, P. Green, S. Glidden, S. E. Bunn, C. A. Sullivan, C. R. Liermann and P. M. Davies, "Global Threats to Human Water Security and River Biodiversity," Nature, Vol. 467, 2010, pp. 555-561. http://dx.doi.org/10.1038/nature09440

[22] The Brisbane Declaration, The Brisbane Declaration at 10th International Riversymposium \& Environmental Flows Conference, Brisbane, 2007.

[23] H. Chen, L. Ma, W. Guo, Y. Yang, T. Guo and C. Feng, 
“Linking Water Quality and Quantity in Environmental Flow Assessment in Deteriorated Ecosystems: A Food Web View," Plos One, Vol. 8, 2013, No. 7, p. 13.

[24] WWF, Fundación Río Arronte, and CONAGUA, “Norma Mexicana de Caudal Ecológico-Una PolíTica Pública Para la Gestión del Agua a Través de la Conservación del Régimen Hidrológico,” Mexico D.F., 2012.

[25] CONAGUA, "Identificación de Reservas Potenciales de agua Para el Medio Ambiente en México,” Comisión Nacional del Agua, Alianza WWF-Fundación Gonzalo Río Arronte I.A.P, Primera Ed. Mexico, 2011, p. 87.

[26] D. L. Tennant, "Instream Flow Regimens for Fish, Wildlife, Recreation and Related Environmental Resources," Fisheries, Vol. 1, No. 4, 1976, pp. 6-10. http://dx.doi.org/10.1577/1548-8446(1976)001<0006:IFR FFW>2.0.CO;2
[27] J. King, R. Tharme and M. de Villier, "Environmental Flow Assessments for Rivers: Manual for the Building Block Methodology,” Water Research Commission, SAF, Cape Town, 2008.

[28] N. L. Poff, B. D. Richter, A. H. Arthington, S. E. Bunn, R. J. Naiman, E. Kendy, M. Acreman, C. Apse, B. P. Bledsoe, M. C. Freeman, J. Henriksen, R. B. Jacobson, J. G. Kennen, D. M. Merritt, J. H. O’Keeffe, J. D. Olden, K. Rogers, R. E. Tharme and A. Warner, "The Ecological Limits of Hydrologic Alteration (ELOHA): A New Framework for Developing Regional Environmental Flow Standards," Freshwater Biology, Vol. 55, No. 1, 2010, pp. $147-170$.

http://dx.doi.org/10.1111/j.1365-2427.2009.02204.x 